\title{
Viral Marketing dan Motivasi Wisatawan dalam Meningkatkan Minat Berkunjung pada Destinasi Wisata di Kabupaten Bima
}

\author{
Sri Ernawati \\ Manajemen, Sekolah Tinggi Ilmu Ekonomi Bima, Indonesia \\ Korespondensi penulis: sriernawati.stiebima@gmail.com
}

\begin{abstract}
Tourism is one of the new style industries, so it needs special attention. The tourism industry can provide rapid economic growth in terms of employment opportunities, income, the standard of living, and inactivating other production sectors. This study aims to analyze and test the effects of viral marketing and tourist motivation both partially and simultaneously in increasing interest in visiting tourist destinations in Bima District, Nusa Tenggara Barat, Indonesia. This research used quantitative methods by distributing questionnaires to 96 people who had visited tourism destinations in Bima District. The questionnaires would be tested for validity and reliability first, and then processed with SPSS version 20.0. Data analysis in this research used multiple linear regression methods with SPSS (Statistical Package for the Social Sciences) 20.0. The results showed that viral marketing and tourist motivation have an effect on tourism destinations and it will positively influence the visiting interest to Bima District, respectively. Simultaneously, viral marketing and tourist motivation can raise visiting interest in Bima District's tourism destinations.
\end{abstract}

Keywords: Bima District; Tourism; Tourist motivations; Viral marketing; Visiting interest.

\begin{abstract}
Abstrak. Pariwisata merupakan salah satu industri gaya baru, sehingga industri tersebut perlu mendapatkan perhatian tersendiri. Industri pariwisata mampu menyediakan pertumbuhan ekonomi yang cepat dalam hal kesempatan kerja, pendapatan, taraf hidup, dan kemampuan mengaktifkan sektor produksi lainnya. Penelitian ini bertujuan untuk menganalisis dan menguji pengaruh viral marketing dan motivasi wisatawan, baik secara parsial maupun simultan untuk meningkatkan minat berkunjung ke destinasi wisata di Kabupeten Bima, Nusa Tenggara Barat, Indonesia. Penelitian ini menggunakan teknik survei untuk menyebarkan kuesioner kepada 96 orang yang pernah berkunjung pada destinasi wisata di Kabupaten Bima. Kuesioner sebagai intrumen penelitian dilakukan pengujian validitas dan reliabilitasnya terlebih dahulu. Selanjutnya, data diolah dan dianalisis menggunakan regresi linier berganda dengan bantuan SPSS (Statistical Package for the Social Sciences) versi 20,0. Hasil penelitian menunjukkan bahwa viral marketing dan motivasi wisatawan secara parsial maupun simultan berpengaruh meningkatkan minat berkunjung mereka ke destinasi wisata di Kabupaten Bima.
\end{abstract}


Kata kunci: Kabupaten Bima; Minat berkunjung; Motivasi wisatawan; Pariwisata; Viral marketing.

Article Info:

Received: January 22, 2020

Accepted: March 3, 2020

Available Online: March 11, 2020

DOI: http://dx.doi.org/10.30588/jmp.v9i2.635

\section{LATAR BELAKANG}

Dewasa ini aktifitas pariwisata dalam kehidupan masyarakat modern menjadi hal yang telah melekat dalam kehidupan sehari-hari. Pariwisata adalah kegiatan manusia yang melakukan perjalanan ke dan tinggal di daerah tujuan di luar lingkungan kesehariannya (Jariah, Mananda, \& Sudiarta, 2018). Sebuah destinasi wisata harus memiliki citra yang baik. Citra suatu destinasi wisata merupakan kombinasi antara persepsi wisatawan dan usaha menyiapkan produk yang memiliki kelebihan dibandingkan dengan pesaing dan nilai lebih daripada harapan wisatawan (Sudiarta, 2012). Pada intinya, membangun citra (image) adalah membangun strategi untuk memuaskan wisatawan dan membangun loyalitas mereka (Sudiarta, 2012).

Media paling efektif untuk melakukan promosi, baik itu barang maupun jasa adalah media sosial (Jariah et al., 2018). Jejaring media sosial memiliki berbagai bentuk pesan, gambar, maupun video. Bentuk-bentuk pesan pada media sosial yang ditayangkan secara terus menerus disebut viral marketing (Jariah et al., 2018). Kelebihan sebuah viral marketing adalah kemampuannya untuk menduplikasikan kegiatan komunikasi pemasaran ke seluruh penjuru jaringan internet. Karena jaringan internet tidak dibatasi oleh waktu maupun zona geografi, maka komunikasi pemasaran dimungkinkan tersebar dan meluas kepada seluruh pengguna internet di seluruh belahan dunia (Ristania \& Justianto, 2012). Sebuah destinasi wisata merupakan kombinasi berbagai elemen yang memberikan pengalaman berbeda dengan tujuan yang sama, yaitu cara untuk memuaskan pengalaman terakhir wisatawan, seperti keinginan untuk datang kembali dan menceritakan pengalaman wisatanya kepada orang lain (Sudiarta \& Suardana, 2016). Dengan demikian, berbagai macam komponen yang ada pada suatu destinasi wisata akan membuka peluang wisatawan menjadi semakin yakin dan percaya untuk memilih suatu daerah sebagai tujuan destinasi wisatanya.

Motivasi merupakan salah satu faktor penting bagi calon wisatawan untuk mengambil keputusan daerah tujuan wisata mana yang akania kunjungi (Pitana \& Gayatri, 2005:58). Di sisi lain, motivasi wisatawan juga merupakan faktor penting untuk meningkatkan industri pariwisata suatu daerah (Pitana \& Gayatri, 2005:58). Setiap wisatawan yang berkunjung ke suatu destinasi wisata memiliki motivasi yang berbeda-beda, sehingga setiap pengelola destinasi wisata suatu daerah harus mampu memahami motivasi wisatawan. Pemahaman tersebut berguna untuk meningkatkan industri pariwisata dan menjadi pemicu wisatawan membuat keputusan pembelian atau keputusan berkunjung ke destinasi wisata (Pitana \& Gayatri, 2005).

Wilson (2000) menyebutkan bahwa viral marketing menggambarkan strategi pemasaran yang mendorong individu untuk menyampaikan pesan kepada orang lain, menciptakan potensi pesan tersebut untuk berkembang dan menyebar seperti virus, dan 
mengambil keuntungan dari strategi penyebaran pesan yang terus berkembang dari ribuan menjadi jutaan. Memasarkan suatu usaha perlu menggunakan strategi pemasaran yang baik dan benar. Pada umumnya, perusahaan memilih strategi pemasaran viral marketing untuk memasarkan produknya agar dapat dijangkau oleh sebanyak mungkin lapisan masyarakat di seluruh wilayah Indonesia, maupun wisatawan mancanegara melalui akses internet (Hamdani \& Mawardi, 2018).

Pada umumnya, wisatawan yang berkunjung ke suatu daerah benar-benar ingin menghabiskan waktunya untuk bersantai, menyegarkan pikiran, dan melepaskan diri dari rutinitas kehidupan sehari-hari (Kusumaningrum, 2009:17). Wisatawan adalah orang yang melakukan perjalanan dari suatu tempat lain yang jauh dari rumahnya bukan karena alasan rumah atau kantor (Kusumaningrum, 2009:17). Pengambilan keputusan mengunjungi destinasi wisata dapat dianggap sebagai kegiatan konsumen memilih produk atau jasa dalam keputusan pembelian (Kotler \& Amstrong, 2012:224). Sebelum melakukan perjalanan wisata, seorang wisatawan terlebih dulu melakukan sebuah proses mental untuk sampai pada keputusan pemilihan, yaitu menyangkut kapan melakukan kunjungan, berapa lama waktu kunjungan, kemana tujuan destinasi wisata, dengan cara bagaimana kunjungan dilakukan, dan seterusnya. Proses pengambilan keputusan ini sangat penting bagi pembangunan pariwisata terkait dengan berbagai fakta yang mempengaruhi keputusan berkunjung ke suatu destinasi wisata (Muksin \& Sunarti, 2018).

Destinasi wisata adalah suatu tempat kunjungan untuk berwisata. Selama perjalanan wisata, wisatawan akan memberikan persepsi terhadap tempat wisata yang dikunjunginya, baik itu persepsi positif yang berarti tempat wisatanya menarik dan akan mengunjunginya secara berulang, dan persepsi negatif yang berarti tempat wisatanya kurang menarik dan ia akan berpikir kembali apabila akan mengunjunginya lagi (Pitana \& Diarta, 2009). Destinasi wisata mempunyai beberapa jenis obyek wisata. Jenis obyek wisata yang banyak dikenal adalah wisata alam, wisata buatan, dan wisata budaya (Pitana \& Diarta, 2009). Setiap daerah mempunyai berbagai destinasi yang dapat menarik minat kunjungan wisatawan, seperti Kabupaten Bima, Nusa Tenggara Barat.

Kabupaten Bima menyimpan banyak kekayaan alam, serta ragam wisata dan budaya yang menjadi salah satu destinasi wisata di Nusa Tenggara Barat (NTB). Kabupaten Bima berjarak $439 \mathrm{~km}$ di ujung timur Provinsi NTB. Lokasi Kabupaten Bima di sebelah timur berbatasan langsung dengan Selat Sape, di sebelah selatan berbatasan dengan Samudera Hindia, dan di sebelah utara berbatasan dengan Laut Flores. Letaknya dikelilingi oleh lautan dengan keberadaan dua gunung api, yaitu Gunung Tambora dan Gunung Sangeang Api. Kondisi tersebut membuat Kabupaten Bima kaya akan ekowisata berupa pantai dan gunung. Lokasi ekowisata yang ada di Kabupaten Bima dipengaruhi oleh letak geografi dan bentuk lahan yang ada. Ekowisata berupa pantai berada di sepanjang pesisir selatan, timur, utara, dan barat daya Kabupaten Bima dengan bentuk lahan marin. Marin merupakan bentuk lahan yang terdapat di sepanjang pantai karena adanya tenaga vulkanisme, diastrofisme, pelipatan, dan patahan, karena Kabupaten Bima berbatasan langsung dengan Samudera Hindia, Selat Sape, dan Laut Flores (Ihsan, Soegiyanto, \& Hadi, 2015).

Sebagian besar obyek wisata di Kabupaten Bima adalah wisata alam pantai, seperti Pantai Pink, Pantai Kelapa, Pulau Ular, dan lain-lain. Selain itu, ada juga obyek wisata Tanjung Mariam dan wisata buatan, seperti Taman Panda, Taman Uma Mee, Mada 
Pangga, Dam Pela Parado, Mata Air Tampuro, dan Oi Wobo, sedangkan wisata budaya meliputi Museum Asi Mbojo (Istana Kerajaan Bima), Uma Lengge, dan Wadu Pa'a (Syafrudin, 2016). Arahan kebijakan pengembangan pariwisata Kabupaten Bima dalam jangka pendek adalah menyusun rencana pengembangan pariwisata daerah, menata sarana dan prasarana wisata dan fasilitas pendukung, menciptakan layanan paket wisata yang profesional, serta melakukan promosi wisata yang efektif. Pengembangan pariwisata merupakan salah satu sumber kegiatan perekonomian masyarakat dan Pendapatan Asli Daerah (PAD), mendukung semakin terpelihara dan berkembangnya nilai budaya lokal, memperkuat potensi dan karakter beberapa kawasan wisata andalan, serta mengembangkan sumber daya manusia (SDM) pariwisata dan investasi (Porosntb.com, 2018).

Suatu destinasi perlu memiliki berbagai fasilitas kebutuhan yang diperlukan oleh wisatawan agar kebutuhan mereka terpenuhi dan merasakan kenyamanan. Berbagai kebutuhan wisatawan tersebut, antara lain fasilitas transportasi, akomodasi, biro perjalanan, atraksi (kebudayaan, rekreasi, dan hiburan), layanan makanan, dan barang-barang cindera mata (Pitana \& Gayatri, 2005:101). Tersedianya berbagai fasilitas kebutuhan akan membuat wisatawan merasa nyaman dan puas, sehingga semakin banyak wisatawan yang ingin berkunjung ke Bima. Permasalahan yang sering dihadapi oleh sektor pariwisata Kabupaten Bima adalah hal paling mendasar, yaitu kurangnya minat masyarakat berkunjung pada destinasi-destinasi wisata di Kabupeten Bima. Hal itu banyak disebabkan oleh kurang tersedianya lokasi wisata yang bersih, terbatasnya fasilitas penunjang dalam area lokasi wisata, banyaknya parkir liar oleh warga masyarakat di sekitar obyek wisata, dan terbatasnya kegiatan promosi oleh Pemerintah Kabupaten Bima.

Berdasarkan uraian latar belakang dan permasalahan di atas, tujuan penelitian ini adalah untuk mengetahui apakah ada pengaruh viral marketing dan motivasi wisatawan terhadap peningkatan minat berkunjung pada destinasi wisata di Kabupaten Bima, baik secara parsial maupun simultan. Dari penelusuran hasil riset terdahulu, penelitian ini belum pernah diteliti sebelumnya, sehingga urgensi penelitian ini adalah upaya untuk memahami peran sosial media dalam membentuk opini masyarakat, sehingga mereka ingin berkunjung pada destinasi wisata di Kabupaten Bima, Nusa Tenggara Barat.

\section{KAJIAN TEORITIS}

\section{Model Penelitian}

Beberapa instrumen yang dapat menstimulasi viral marketing, di antaranya adalah customer recommendation (rekomendasi pelanggan), newsletter, lingking strategies, communities (komunitas), free offer (penawaran gratis), sweepstakes (undian), list of prospective buyers (daftar konsumen potensial), chatrooms (tempat obrolan), reference list (daftar referensi), product-texts (teks produk), affiliate programs (program afiliasi), dan search engine (mesin pencari) (Skrob, 2005:12). Peran kunci viral marketing adalah mendapatkan pengunjung website dan merekomendasikannya kepada orang lain yang dianggap akan tertarik. Mereka akan menghubungkan pesan tersebut kepada konsumen potensial yang akan menggunakan barang atau jasa yang ditawarkan, serta merekomendasikannya kepada konsumen lain (Hamdani \& Mawardi, 2018). 
Kemajuan teknologi informasi, seperti perkembangan sosial media banyak mengubah cara masyarakat mendapatkan informasi terkait pariwisata dan cara mereka merencanakan, serta melakukan kunjungan wisata yang disebarluaskan kepada orang lain dengan lebih mudah dan cepat. Motivasi perjalanan wisata dipengaruhi oleh dua faktor penting, yaitu faktor pendorong (push) dan faktor penarik (pull). Beberapa faktor pendorong wisatawan untuk mengunjungi suatu destinasi wisata, di antaranya (Woodside \& Martin, 2008): (1) Desire to escape (keinginan untuk berlibur), (2) Rest and Relaxatin (istirahat dan relaksasi), (3) Prestige (kebanggaan), (4) Social Interaction (interaksi sosial), (5) Health and Fitness (kesehatan dan kebugaran), dan (6) Adventure (petualangan). Selain itu, faktor-faktor penarik wisatawan berkunjung ke destinasi wisata meliputi (Manik, Suwena \& Suardana, 2016): (1) cultural/historical (budaya/sejarah), (2) affordable price (harga yang terjangkau), (3) variety seeking (banyak pilihan tempat wisata), (4) tourism facilities (fasilitas pariwisata), (5) safety and clean (aman dan bersih), serta (6) environment (lingkungan).

Model penelitian yang digunakan dalam penelitian ini disajikan pada Gambar 1 berikut ini. Berdasarkan model penelitian tersebut, variabel-variabel dan hubungan antarvariabel yang dikaji dalam penelitian ini diuraikan sebagai berikut:

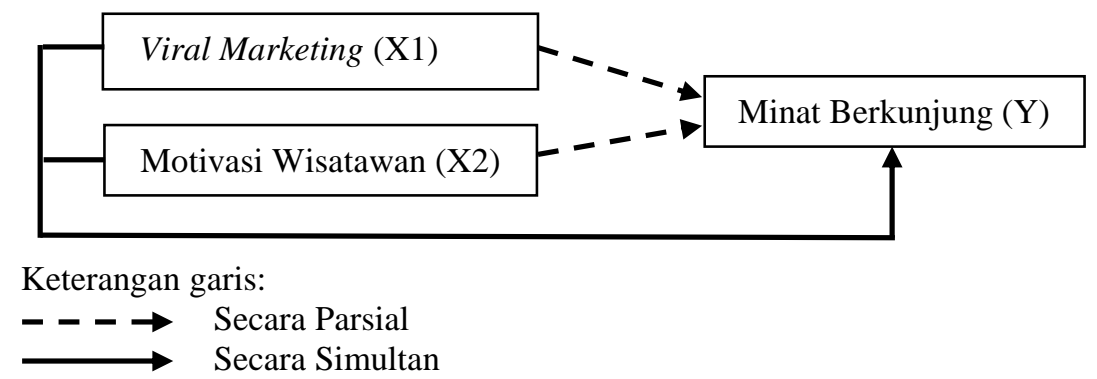

Gambar 1. Model Penelitian

\section{Viral marketing dan Minat Berkunjung pada Destinasi Wisata}

Viral marketing pada dasarnya merupakan bentuk pemasaran dari mulut ke mulut berbasis internet (e-mouth to mouth marketing atau disebut juga dengan istilah $e$-WOM marketing) yang fungsi promosinya bersifat networking dan dirancang seperti virus menjangkiti dari satu orang ke orang lainnya secara cepat dan luas dengan memberikan imbalan khusus kepada konsumennya (Hasan, 2010:42). Secara konseptual, cara kerja viral marketing terjadi layaknya sebuah penyebaran virus, yaitu memperbanyak dirinya sendiri. Viral marketing ini merupakan sebuah upaya promosi yang memanfaatkan kekuatan informasi words of mouth (WOM). Dalam dunia online, jika penyebarannya digunakan dengan tepat melalui media, maka dampaknya dapat memberikan manfaat yang besar, mempererat komunikasi dengan teman atau saudara yang berjauhan, bertukar informasi, dan bahkan bisa dijadikan sebagai tempat atau wadah untuk mempromosikan bisnis yang sedang dikerjakan (Glennardo, 2016).

Pemasaran WOM dapat terjadi dengan sendirinya tanpa disengaja. Namun, semua informasi tersebut selalu memiliki sumber dan ada pihak yang memperkuatnya, sehingga komunikasi dapat menyebar dengan lebih cepat. Pemasar dapat berperan sebagai 
sumber. Selain itu, pemasar juga dapat menjadi pemacu tersebarnya komunikasi dari mulut ke mulut tersebut (Surniandari, 2017). Penelitian yang dilakukan oleh Jariah et al. (2018) menyatakan bahwa viral marketing berpengaruh terhadap jumlah kunjungan wisatawan Indonesia ke Korea Selatan, sedangkan Hidayati (2018) menyebutkan bahwa viral marketing berpengaruh signifikan terhadap keputusan pembelian produk Shopee di Surabaya. Dari uraian tersebut, penelitian ini mengajukan hipotesis kesatu (H1) sebagai berikut:

\section{H1: Viral marketing memiliki pengaruh dalam meningkatkan minat berkunjung pada destinasi wisata di Kabupaten Bima.}

\section{Motivasi Wisatawan dan Minat Berkunjung pada Destinasi Wisata}

Motivasi adalah sebuah dorongan yang timbul dari dalam diri seseorang yang menyebabkannya bertindak tanpa disadari dan mempengaruhi tingkah lakunya agar ia tergerak hatinya untuk bertindak, sehingga ia mampu mencapai hasil atau tujuan tertentu (Sudirman, 2011). Penelitian yang dilakukan oleh Muksin dan Sunarti (2018) menyebutkan bahwa motivasi wisata mempunyai pengaruh signifikan terhadap keputusan berkunjung wisatawan di lokasi ekowisata mangrove Wonorejo Surabaya dan penelitian Harsono (2017) menyatakan bahwa masing-masing individu mempunyai motivasi yang berbeda tergantung pada keinginan wisata yang ingin dicapai dan jika obyek wisata tersebut dapat memenuhi kriteria yang diinginkan, maka obyek tersebut akan menjadi pilihan. Dari uraian tersebut, penelitian ini mengajukan hipotesis kedua $(\mathrm{H} 2)$ sebagai berikut:

\section{H2: Motivasi wisatawan memiliki pengaruh dalam meningkatkan minat berkun- jung pada destinasi wisata di Kabupaten Bima.}

Menciptakan sesuatu yang viral perlu memperhatikan etika berinternet dan aturan hukum yang berlaku, karena viral yang diciptakan akan tersebar luas dan menimbulkan persepsi berbeda oleh penerimanya. Sebaiknya, sebelum melakukan unggahan di media sosial, siapa pun harus memperhatikan hal-hal apa yang dilarang untuk dilakukan (Widjaja \& Alexandra, 2019). Minat merupakan kekuatan pendorong yang menyebabkan seseorang menaruh perhatian pada orang atau obyek lain. Minat merupakan salah satu sumber motivasi seseorang untuk melakukan kegiatan yang disukai dan berdampak terhadap peningkatan pangsa pasar.

Purba (2016) menyebutkan bahwa semakin baik viral marketing, maka penyebaran tersebut akan diikuti oleh semakin tingginya minat beli konsumen terhadap produk Indihome pada PT Telekomunikasi Indonesia, Tbk. Bandung. Pada penelitian lainnya, Sahara dan Sanawiri (2016) menyebutkan bahwa motivasi wisatawan untuk berkunjung ke Kota Batu terutama mengunjungi obyek wisata alam dan buatan (man-made), tidak terlepas dari informasi yang didapatkan mengenai destinasi di Kota Batu dan produkproduk unggulan wisata yang ada di kota tersebut. Dari uraian tersebut, penelitian ini mengajukan hipotesis ketiga (H3) sebagai berikut:

\section{H3: Viral marketing dan motivasi wisatawan secara simultan memiliki pengaruh untuk meningkatkan minat berkunjung pada destinasi wisata di Kabupaten Bima.}




\section{METODE PENELITIAN}

Lokasi penelitian ini berada di Kabupaten Bima, Provinsi Nusa Tenggara Barat. Penelitian ini menggunakan metode kuantitatif dengan pendekatan survei. Instrumen pengumpulan data dalam penelitian ini adalah kuesioner, sedangkan pengukuran variabel penelitian menggunakan skor yang mengacu pada skala Likert yang digunakan untuk mengukur sikap, pendapat, dan persepsi seseorang atau sekelompok orang tentang fenomena sosial (Sugiyono, 2011). Pembobotan pada pengukuran masing-masing variabel diberikan pilihan jawaban Sangat Setuju (SS) dengan skor 5, Setuju (S) skor 4, Netral (N) skor 3, Tidak Setuju (TS) skor 2, dan Sangat Tidak Setuju (STS) skor 1. Pengukuran setiap variabel dalam penelitian ini menggunakan indikator yang dijelaskan pada Tabel 1 berikut ini.

Tabel 1. Pengukuran Variabel Penelitian

\begin{tabular}{ll}
\hline \multicolumn{1}{c}{ Variabel } & \multicolumn{1}{c}{ Indikator dan Referensi } \\
\hline \multirow{3}{*}{ Viral Marketing } & $\begin{array}{l}\text { (1) Information spreading, (2) Credibility of information, (3) Expressing } \\
\text { positive feelings, (4) Economic incentive, dan (5) Helping the company. } \\
\text { (Alkharabsheh, Alsarayreh, Rumman, \& Alfarajat, 2011; Hasan \& }\end{array}$ \\
& $\begin{array}{l}\text { Setyaningtiyas, 2015). } \\
\text { Motivasi Wisatawan }\end{array}$ \\
\hline \multirow{3}{*}{ Minat Berkunjung } & $\begin{array}{l}\text { (1) Physical motivation, (2) Cultural motivation, (3) Social motivation atau } \\
\text { (Pitana \& Gayatri. 2005). }\end{array}$ \\
& $\begin{array}{l}\text { (1) Minat transaksional, (2) Minat referensial, (3) Minat preferensial, dan (4) } \\
\text { Minat eksploratif. } \\
\text { (Ferdinand, 2014) }\end{array}$ \\
\hline
\end{tabular}

Sumber: Referensi terkait.

Penelitian ini menggunakan data pimer yang langsung diperoleh dari sumber pertama, yaitu masyarakat yang pernah berkunjung ke desnitasi wisata pesisir laut, hutan bakau, sungai, taman, dan pegunungan di Kabupaten Bima yang jumlahnya tidak bisa diketahui secara pasti (unknow population). Jumlah masyarakat yang berkunjung ke destinasi wisata sangat banyak dan tidak mungkin meneliti semuanya karena adanya keterbatasan, sehingga pengambilan sampel perlu dilakukan dengan rumus seperti yang ditunjukkan pada persamaan [1] (Atmaja, 2009).

$$
\boldsymbol{n}=\frac{\mathrm{Z}^{2}}{\mathbf{4 ( \mathbf { m o e } ) ^ { 2 }}}
$$

Keterangan:

$\mathrm{n} \quad=$ Jumlah sampel.

$\mathrm{Z} \quad=\mathrm{Z}$ score pada tingkat signifikansi tertentu.

Nilai $Z=1,96$ dengan tingkat kepercayaan $95 \%$.

Moe = Margin of error atau tingkat kesalahan maksimum adalah $10 \%$.

Berdasarkan formulasi di atas, maka jumlah sampel yang digunakan dalam penelitian ini sebanyak:

$n=\frac{1,96^{2}}{(4)(0,10)^{2}}=96,4=96$ responden (pembulatan).

Berdasarkan perhitungan pada persamaan [1], jumlah sampel yang digunakan sebanyak 96 orang responden. Teknik pengambilan sampel menggunakan accidental sampling, yaitu pengambilan sampel secara kebetulan. Pada saat proses pengumpulan data, 
maka siapa pun yang peneliti temukan di beberapa obyek wisata di Kabupaten Bima dapat dipilih menjadi responden. Metode analisis yang digunakan dalam penelitian ini adalah analisis regresi linier berganda, yaitu untuk mengetahui pengaruh viral marketing dan motivasi wisatawan dalam meningkatkan minat berkunjung pada destinasi wisata di Kabupaten Bima. Model persamaan regresi linier berganda dalam penelitian ini ditunjukkan pada persamaan [2].

$$
\mathbf{Y}=\mathbf{a}+\mathbf{b}_{1} \mathbf{x}_{1}+\mathbf{b}_{2} \mathbf{x}_{2}+\mathbf{e}
$$

Keterangan:

$\mathrm{Y}=$ Minat berkunjung

A $=$ Konstanta

$\mathrm{b}_{\mathrm{n}} \quad=$ beta

$\mathrm{X}_{1} \quad$ Viral marketing

$\mathrm{X}_{2}=$ Motivasi wisatawan

$\mathrm{e}=$ error

\section{HASIL PENELITIAN DAN PEMBAHASAN}

\section{Profil Responden}

Dari 96 kuesioner yang disampaikan kepada responden, semuanya mengembalikan kuesioner yang telah diisi, karena teknik yang digunakan adalah accidental sampling, sehingga jawaban responden dapat langsung diperoleh pada saat penyebaran kuesioner. Gambaran umum responden dalam penelitian ini dapat dilihat dari karakteristik responden yang meliputi jenis kelamin, pendidikan, dan pekerjaan. Gambaran umum mengenai profil responden dalam penelitian ini ditunjukkan pada Tabel 2.

Tabel 2. Karakteristik Responden

\begin{tabular}{llcc}
\hline Karakteristik & \multicolumn{1}{c}{ Kriteria } & Jumlah Responden & Persentase \\
\hline Jenis Kelamin & Perempuan & 76 & 70,10 \\
& Laki-laki & 20 & 20,83 \\
\hline Pendidikan & Strata dua (S2) & 2 & 2,08 \\
& Strata satu (S1) & 67 & 69,80 \\
& Ahli Madya (D3) & 19 & 19,80 \\
& SMA (Sekolah Menengah Atas) & 8 & 8,33 \\
\hline Pekerjaan & ASN (Aparatur Sipil Negara) & 34 & 35,40 \\
& Pegawai Swasta & 19 & 19,80 \\
& Wirausaha & 27 & 28,12 \\
& IRT (Ibu Rumah Tangga) & 16 & 16,66 \\
\hline
\end{tabular}

Keterangan: $n=96$

Sumber: Data primer diolah dengan SPSS versi 20,0 (2019).

Berdasarkan Tabel 2 tersebut, mayoritas responden berjenis kelamin perempuan yaitu $70,10 \%$. Selain itu, mayoritas responden berpendidikan Strata satu (S1), yaitu $69,80 \%$, dan mayoritas pekerjaan mereka adalah ASN, yaitu 35,40\%.

\section{Uji Validitas}

Hasil pengukuran validitas intrumen penelitian ini tersaji pada Tabel 3. Data hasil pengujian di Tabel 3 menunjukkan uji validitas, yaitu nilai corrected item-total correla- 
tion>0,300 (r-tabel). Hasil uji validitas ini menunjukkan bahwa setiap butir penyataan dalam kuesioner untuk setiap variabel penelitian yang digunakan dinyatakan valid.

Tabel 3. Hasil Uji Validitas

\begin{tabular}{cccccc}
\hline Butir & r-hitung X1 & r-hitung X2 & r-hitung Y & r-tabel & Keterangan \\
\hline 1 & .577 & .688 & .755 & .300 & Valid \\
\hline 2 & .581 & .896 & .687 & .300 & Valid \\
\hline 3 & .517 & .580 & .682 & .300 & Valid \\
\hline 4 & .785 & .553 & .787 & .300 & Valid \\
\hline 5 & .887 & .682 & .570 & .300 & Valid \\
\hline 6 & .918 & .895 & .541 & .300 & Valid \\
\hline 7 & .599 & .580 & .557 & .300 & Valid \\
\hline 8 & .683 & .891 & .773 & .300 & Valid \\
\hline 9 & .539 & .896 & .790 & .300 & Valid \\
\hline 10 & .340 & .692 & .541 & .300 & Valid \\
\hline
\end{tabular}

Sumber: Data primer diolah dengan SPSS versi 20,0 (2019).

\section{Uji Reliabilitas}

Hasil uji reliabilitas ditunjukkan pada Tabel 4. Data pengujian di Tabel 4 menunjukkan hasil uji reliabilitas dengan nilai Cronbach's alpha>0,600. Hasil pengujian tersebut menunjukkan bahwa butir-butir pernyataan kuesioner pada setiap variabel dinyatakan reliabel.

Tabel 4. Hasil Uji Reliabilitas

\begin{tabular}{lcc}
\hline Variabel & Cronbach 's Alpha & Keterangan \\
\hline Viral Marketing (X1) & .840 & Reliabel \\
\hline Motivasi Wisatawan (X2) & .899 & Reliabel \\
\hline Minat Berkunjung (Y) & .805 & Reliabel \\
\hline Sumber: Data primer diolah dengan SPSS versi 20,0 (2019).
\end{tabular}

\section{Uji Hipotesis}

Untuk mengetahui apakah hipotesis yang diajukan dalam penelitian ini diterima atau ditolak, maka pengujian hipotesis dilakukan menggunakan uji $\mathrm{t}$ (parsial) dan uji $\mathrm{F}$ (simultan). Hasil pengujian hipotesis dijelaskan dalam uraian berikut ini.

\section{Hasil Uji t (Parsial)}

Uji t bertujuan untuk menguji hipotesis $\mathrm{H}_{1}$ dan $\mathrm{H}_{2}$, yaitu pengaruh viral marketing dan motivasi wisatawan terhadap minat berkunjung pada destinasi wisata di Kabupaten Bima secara parsial. Hasil uji t penelitian ini tersaji pada Tabel 5.

\section{$\mathrm{H}_{1}$ : Viral Marketing berpengaruh meningkatkan Minat Berkunjung pada destinasi wisata di Kabupaten Bima.}

Hasil statistik uji t untuk variabel viral marketing memperoleh nilai $\mathrm{t}_{\text {hitung }}$ sebesar 7,092 dengan nilai $t_{\text {tabel }}$ sebesar 1,985 $(7,092>1,985)$ dengan nilai signifikansi sebesar 0,000 lebih kecil dari $0,05(0,00<0,05)$, dan koefisien regresi mempunyai nilai positif sebesar 0,502 , maka hipotesis $\mathrm{H}_{1}$ yang menyatakan bahwa viral marketing berpengaruh 
dalam meningkatkan minat berkunjung pada destinasi wisata di Kabupaten Bima dapat diterima.

Tabel 5. Hasil Uji t (Secara Parsial)

Coefficients $^{\text {a }}$

\begin{tabular}{|c|c|c|c|c|c|c|}
\hline & \multirow{2}{*}{ Model } & \multicolumn{2}{|c|}{ Unstandardized Coefficients } & \multirow{2}{*}{$\begin{array}{c}\text { Standardized } \\
\text { Coefficients } \\
\text { Beta }\end{array}$} & \multirow{2}{*}{$\mathrm{t}$} & \multirow{2}{*}{ Sig. } \\
\hline & & $\mathrm{B}$ & Std. Error & & & \\
\hline \multirow{3}{*}{1} & (Constant) & 8,272 & 2,207 & - & 3,749 & 0,000 \\
\hline & Viral Marketing & 0,502 & 0,071 & 0,533 & 7,092 & 0,000 \\
\hline & Motivasi Wisatawan & 0,320 & 0,061 & 0,394 & 5,244 & 0,000 \\
\hline
\end{tabular}

${ }^{a}$ Dependent Variable: Minat Berkunjung.

Sumber: Data diolah dengan SPSS versi 20,0 (2019).

Responden pada penelitian ini lebih didominasi oleh perempuan, sedangkan viral marketing merupakan turunan dari word of mouth (WOM) yang lebih cepat menyebar di media sosial (Gobert, 2006:3). Perempuan cenderung lebih cepat menyebarkan berita atau informasi dan sekaligus juga lebih cepat menerima informasi melalui media sosial. Hal tersebut dikarenakan perempuan merupakan makhluk yang lebih senang berinteraksi. Mereka lebih sering menceritakan kesehariannya di media sosial. Perempuan lebih intensif membagi informasi dengan teman, mempelajari hal positif, mendapatkan dukungan dari jaringan pertemanan, maupun sekedar berbagi hiburan atau konten unik dan menarik, seperti tempat hiburan, kuliner, obyek wisata, dan lain-lain.

Berdasarkan hasil penelitian ini, kunjungan wisatawan ke destinasi wisata di Kabupaten Bima berpotensi mengalami peningkatan, berawal dari peran media sosial yang efektif untuk melakukan promosi, sehingga daerah pesisir pantai yang sebelumnya tidak dikenal dan terasa asing akan menjadi sebuah tempat berkunjung yang menjadi prioritas untuk dikunjungi. Hal ini dapat memberikan dampak pada kehidupan masyarakat sekitar obyek wisata. Perekonomian masyarakat sekitar akan meningkat seiring meningkatnya jumlah wisatawan yang berkunjung. Banyak masyarakat yang tinggal di daerah sekitar obyek wisata membuka usaha lesehan ikan bakar, minuman dingin, beruga (tempat duduk), tempat parkir, dan lain-lain.

\section{H2: Motivasi Wisatawan berpengaruh meningkatkan Minat Berkunjung pada des- tinasi wisata di Kabupaten Bima.}

Hasil statistik uji $\mathrm{t}$ untuk variabel motivasi wisatawan memperoleh nilai $\mathrm{t}_{\text {hitung }}$ sebesar 5,244 dengan nilai $t_{\text {tabel }}$ sebesar $1,985(5,244>1,985)$ dengan nilai signifikansi sebesar 0,000 lebih kecil dari $0,05(0,00<0,05)$, dan koefisien regresi mempunyai nilai positif sebesar 0,320 , maka hipotesis $\mathrm{H}_{2}$ yang menyatakan bahwa motivasi wisatawan berpengaruh dalam meningkatkan minat berkunjung pada destinasi wisata di Kabupaten Bima dapat diterima.

Hasil penelitian ini menunjukkan adanya keterkaitan antara motivasi dan minat berkunjung. Berdasarkan identifikasi responden, motivasi wisatawan berkunjung ke destinasi wisata di Kabupeten Bima sangat beragam. Misalnya, mereka menginginkan ketenangan setelah melakukan rutinitas pekerjaan, ingin mendapatkan pengakuan karena pernah berkunjung pada obyek wisata yang sedang viral, dan ingin mengetahui adat istiadat, budaya, kesenian tradisional, dan peninggalan bersejarah dari nenek moyang 
masyarakat Bima, sehingga motivasi mereka ketika berkunjung pun sangat beragam. Hal tersebut tergantung pada keinginan masing-masing individu yang disesuaikan dengan kebutuhan mereka. Wisatawan akan mendapatkan apa yang mereka butuhkan, ketika mereka mengunjungi destinasi wisata di Kabupaten Bima. Wisatawan akan merasa puas dengan keindahan alamnya dan mereka akan termotivasi untuk berencana melakukan kunjungan kembali di saat liburan mendatang.

\section{Uji F (Simultan)}

Uji $\mathrm{F}$ bertujuan untuk menguji hipotesis $\mathrm{H}_{3}$, yaitu Viral Marketing dan Motivasi Wisatawan berpengaruh terhadap peningkatan Minat Berkunjung pada destinasi wisata di Kabupaten Bima secara simultan dari data yang ditunjukkan pada Tabel 6.

Tabel. 6 Hasil Uji F (Secara Simultan)

\begin{tabular}{|c|c|c|c|c|c|c|}
\hline & \multicolumn{6}{|c|}{ ANOVA $^{a}$} \\
\hline & Model & Sum of Squares & df & Mean Square & $\mathbf{F}$ & Sig. \\
\hline & Regression & 1235,851 & 2 & 617,925 & 128,999 & $0,000^{\mathrm{b}}$ \\
\hline 1 & Residual & 445,483 & 93 & 4,790 & & \\
\hline & Total & 1681,333 & 95 & & & \\
\hline
\end{tabular}

${ }^{\mathrm{a}}$ Dependent Variable: Minat Berkunjung.

bredictors: (Constant), Motivasi Wisatawan, Viral Marketing.

\section{H3: Viral Marketing dan Motivasi Wisatawan berpengaruh secara simultan dalam meningkatkan Minat Berkunjung pada destinasi wisata di Kabupaten Bima.}

Hasil statistik uji $\mathrm{F}$ untuk variabel viral marketing dan motivasi wisatawan memperoleh nilai $F_{\text {hitung }}$ sebesar 128,999 dengan nilai $F_{\text {tabel }}$ sebesar 3,09 (128,999>3,09) dengan nilai signifikansi sebesar 0,000 lebih kecil dari $0,05(0,00<0,05)$, maka hipotesis $\mathrm{H}_{3}$ yang menyatakan bahwa Viral Marketing dan Motivasi Wisatawan secara simultan berpengaruh dalam meningkatkan Minat Berkunjung pada destinasi wisata di Kabupaten Bima dapat diterima.

Berdasarkan hasil penelitian ini, media sosial mempunyai peran sangat penting untuk memviralkan sebuah destinasi wisata. Jejaring media sosial memiliki berbagai bentuk penyampaian pesan, seperti gambar, video, dan pesan yang menarik, sehingga motivasi wisatawan untuk berkunjung pada destinasi wisata di Kabupaten Bima dapat terpicu karenanya. Motivasi wisatawan yang sangat beragam merupakan faktor yang perlu diperhatikan dalam upaya meningkatkan industri pariwisata di daerah, karena hal itu dapat menjadi pendorong minat wisatawan untuk berkunjung.

\section{KESIMPULAN DAN SARAN}

Berdasarkan hasil penelitian dan pembahasan tersebut di atas, maka variabel viral marketing dan motivasi wisatawan berpengaruh signifikan dalam meningkatkan minat berkunjung wisatawan pada destinasi wisata di Kabupaten Bima, Nusa Tenggara Barat, baik secara parsial maupun simultan. Keterbatasan penelitian ini adalah lokasi penelitian yang cukup jauh, karena obyek wisata yang berlokasi di Kabupaten Bima sebagian besar berada di daerah pelosok dan masih banyak variabel-variabel lain yang dapat diteliti lebih lanjut, seperti daya tarik, fasilitas, servicescape, dan lain-lain yang sesuai dengan keadaan subyek maupun obyek wisata di Kabupaten Bima. 
Saran yang dapat diberikan dari hasil penelitian ini adalah Pemerintah Kabupaten Bima harus berperan aktif dalam upaya meningkatkan kunjungan wisatawan pada obyek-obyek wisata di Kabupaten Bima, karena upaya tersebut dapat pula meningkatkan PAD dengan senantiasa mengupayakan promosi secara lokal, nasional, maupun internasional melalui media massa/sosial, seperti facebook dan instagram. Selanjutnya, pemerintah daerah sebaiknya memiliki web khusus yang berkaitan dengan destinasi wisata di Kabupaten Bima dan meningkatkan fungsi fasilitas penunjang obyek wisata agar motivasi wisatawan berkunjung dapat selalu ditingkatkan.

\section{DAFTAR REFERENSI}

Alkharabsheh, S. K., Al Sarayreh, N. M., Rumman, A. M., \& Al Farajat, H. A. (2011). The Impact of Viral Marketing via Internet on Promotion of Tourism Products in Jordan. International Research Journal of Finance and Economics, 80, 139-147.

Atmaja, L. S. (2009). Statistik untuk Bisnis dan Ekonomi. Yogyakarta: Andi Offset.

Ferdinand, A. (2014). Metode Penelitian Manajemen. Semarang: BP Universitas Diponegoro.

Glennardo, Y. (2016). Viral marketing sebagai Media Pemasaran Sosial dalam Mendongkrak Kesadaran Masyarakat untuk Berperan Aktif dan Bergabung dengan Organisasi Non Profit/Nirlaba. Competence Journal of Management Studies, 16 (2), 192-208.

Gobert, D. (2006). Legality of Viral Marketing. Bruxelles, Belgium. http://mineco.fgov. be/information_society/spamming/home_en.html.

Hamdani, Y. M. \& Mawardi, Y. M. (2018). Pengaruh Viral Marketing terhadap Kepercayaan Konsumen serta Dampaknya terhadap Keputusan Pembelian (Survei pada Mahasiswa Fakultas Ilmu Administrasi Universitas Brawiijaya Angkatan 2015/ 2016 yang Pernah Melakukan Pembelian Online melalui Media Sosial Instagram). Jurnal Administrasi Bisnis (JAP), 60(1), 163-171.

Hasan, A. (2010). Marketing dari Mulut ke Mulut. Yogyakarta: Media Pressindo.

Hasan, A. \& Setyaningtiyas, N. W. (2015). Pengaruh Electronic Word of Mouth pada Media Sosial Facebook terhadap Keputusan Berkunjung ke Desa Wisata Nglanggeran Gunungkidul. Jurnal Media Wisata, 13(1), 224-238.

Harsono, R. N. (2017). Motivasi Wisatawan Mengunjungi Obyek Wisata di Desa Pawan Kabupaten Rokan Hulu. Jurnal Online Mahasiswa FISIP, 4(1), 1-14.

Hidayati, L. N. (2018). Pengaruh Viral Marketing, Online Consumer Reviews dan Harga terhadap Keputusan Pembelian Shopee di Surabaya. Jurnal Pendidikan Tata Niaga (JPTN), 06(03), 77-84.

Ihsan, Soegiyanto, \& Hadi, P. (2015). Pengembangan Potensi Ekowisata di Kabupaten Bima. Jurnal Geoeco, 1(2), Juli, 195-206.

Jariah, I. A., Mananda, S. I. G. P. B., \& Sudiarta (2018). Pengaruh Viral Marketing terhadap Jumlah Kunjungan Wisatawan Indonesia ke Korea Selatan. Jurnal IPTA, $5(1), 1-10$.

Kusumaningrum, D. (2009). Persepsi Wisatawan Nusantara terhadap Daya Tarik Wisata di Kota Palembang. Tesis. Program Magister Kajian Pariwisata, Universitas Gadjah Mada, Yogyakarta. 
Kotler, P. \& Amstrong, G. (2012). Prinsip-prinsip Pemasaran. Edisi 13, Jilid 1. Jakarta: Penerbit Erlangga.

Manik, G., Suwena, I. K., \& Suardana, I. W. (2016). Faktor Pendorong dan Penarik Wisatawan Backpacker Mancanegara Berwisata Ke Bali. Jurnal IPTA, 4(2), 1-20.

Muksin, M. R. D. \& Sunarti (2018). Pengaruh Motivasi terhadap Keputusan Berkunjung Wisatawan di Ekowisata Mangrove Wonorejo Surabaya. Jurnal Administrasi Bisnis (JAB), 55(1), Februari, 196-203.

Pitana, I. G. \& Gayatri, P. G. (2005). Sosiologi Pariwisata. Yogyakarta: Andi Offset.

Pitana, I. G. \& Diarta, I. K. S. (2009). Pengantar Ilmu Pariwisata. Yogyakarta: Andi Offset.

Porosntb.com (2018). Bupati Bima Paparkan Arah Pengembangan Pariwisata Daerah. Diakses 27 Juni 2019 dari http://www.porosntb.com/2018/04/bupati-bima-papar kan-arah-pengembangan.html.

Ristania, N. \& Justianto, S. J. (2012). Analisis Pengaruh Harga, Promosi dan Viral Marketing terhadap Keputusan Pembelian pada "Online Shop" S-Nexian melalui Facebook. Journal of Business Strategy and Execution, 6(2), 131-161.

Purba, S. R. (2016). Pengaruh Viral Marketing melalui Aplikasi Line terhadap Keputusan Pembelian (Studi Kasus Mahasiswa Telkom University pada Tahun 2016). $e$ Pro-ceeding of Applied Science, 2(2), 470-474.

Sahara, R. N. A. \& Sanawiri, B. (2016). Analisis Motivasi Berkunjung Wisatawan dan Tingkat Pengetahuan Wisatawan tentang Produk Industri Reaktif Sektor Kerajinan (Studi pada Wisatawan Domestik di Kota Batu, Jawa Timur). Jurnal Administrasi Bisnis (JAB), 35(2), 146-154.

Skrob, J. R. (2005). Open Source and Viral Marketing. Vienna: http://www.fh.kufstein. ac.at.

Sudiarta, I. N. (2012). Membangun Citra (Destinasi) Pariwisata Seberapa Pentingkah? Jurnal Ekonomi dan Pariwisata, 7(31), 60-75.

Sudiarta, I. N. \& Suardana, I. W. (2016). Tourism Destination Planning Strategy: Analysis and Implementation of Marketing City Tour in Bali. Procedia - Social and Behavioral Sciences, 227, 664-670.

Sudirman (2011). Interaksi dan Motivasi Belajar Mengajar. Jakarta: Grafindo Persada.

Sugiyono (2011). Metode Penelitian Kuantitatif, Kualitatif dan R\&D. Bandung: Alfabeta.

Surniandari, A. (2017). Viral Marketing sebagai Alternatif Strategi Pemasaran Produk Sariz. Widya Cipta, I(1), 35-44.

Syafrudin (2016). 20 Tempat Wisata di Bima NTB yang Wajib Dikunjungi. Diakses 25 Juni 2019 dari http://syafrudinmtop.net/2016/11/bima/20-tempat-wisata-di-bimantb-yang-wajib-dikunjungi.html.

Widjaja, R. Y. \& Alexandra, R. (2019). The Impact of Viral Marketing on Consumer Interest on Indihome Product. e-Jurnal Apresiasi Ekonomi, 7(1), 103-107.

Wilson, F. R. (2000). The Six Simple Principles of Viral Marketing. Web Marketing Today, 70, 232.

Woodside, A. G. \& Martin, D. (2008). Tourism Management: Analysis, Behaviour and Strategy. London: CAB International. 